\title{
SUSTAINABLE AGRICULTURE - DEVELOPING COUNTRIES PERSPECTIVE
}

\author{
Jacek UZIAK ${ }^{1}$, Edmund LORENCOWICZ ${ }^{2}$ \\ ${ }^{1}$ University of Botswana, BOTSWANA \\ ${ }^{2}$ University of Life Sciences in Lublin, POLAND \\ E-mail of corresponding author: uziak@mopipi.ub.bw
}

Keywords: sustainable agriculture, developing countries, knowledge, participation, cooperation

\begin{abstract}
The paper discusses the factors affecting the sustainable agriculture and its adoption in the developing countries. It argues the importance of economic aspect of sustainable agriculture and the necessity of meeting farmers expectations in terms of production and output. An introduction of realistic learning framework promoting sustainable agricultural practices, with active participation and cooperation, is also introduced and debated.
\end{abstract}

\section{INTRODUCTION}

Agriculture is critical for human welfare and economic growth. That applies to both developed and developing world. However, it has a particular significance in countries where people still live in extreme poverty with subsistence agriculture as their main source of food and income. Typically, in most developing countries, people depend on farming for their livelihood (Toenniessen, Adesina \& DeVries, 2008).

With the increasing world population, especially in the developing countries, global food demand is projected to double over the next 50 years (Hunter et al., 2017); with many authors calling for production increases of $60 \%-100 \%$ by 2050 , based on two recent food-demand projections (Tilman et al., 2011, Alexandratos \& Bruinsma, 2012). Need to increase agricultural productivity and food security in a sustainable manner poses a huge challenge, especially in areas now referred to as developing countries. It is difficult to imagine that those areas will move towards, so called, developed countries.

Increasing presence in the media issues related to climate change, usable land for agriculture, availability of water and waste management brought a lot of attention to the environmental aspect of sustainability. However, it is crucial to remember about the other fundamental elements; economic sustainability and social sustainability.

It may be hard to comprehend, for those who do not realize the conditions of living in the developing countries, but for smallholder farmer living in some rural area of Africa, Asia or South America the food production is the most important aspect of agricultural activity. His awareness of the ecological issues may be either low or not existent, whereas his concern is solely related to practical problems of his equipment and activities. Such farmer is still using mainly animal power and manual labour for farming, hence his concern may be with proper harness for his donkeys (Barro, Kondombo \& Yelemou, 2017; Getnet et al., 2014), adequate plough for his oxen (Loukanov, Uziak, Michálek, 2005) or proper hand driven equipment for food processing (Uziak \& Loukanov, 2007). In addition, many traditional agricultural systems and techniques stood the test of time. They document successful and resilient indigenous agricultural strategies and by itself represent an example of sustainable system (Altieri \& Toledo, 2011). In that context, sustainable agriculture may be reflected upon differently. 


\section{DEFINITION OF SUSTAINABLE AGRICULTURE}

Food and Agriculture Organization of the United Nations (FAO) defines sustainable agriculture development as 'the management and conservation of the natural resource base, and the orientation of technological and institutional change in such a manner to ensure the attainment and continued satisfaction of human needs for present and future generations.' (FAO, 1995). In fact, in an agricultural context the concept of sustainability came by much earlier. One of the earlier definitions specifies a sustainable agriculture as a system that, 'over the long term, enhances environmental quality and the resource base on which agriculture depends; provides for basic human food and fibre needs; is economically viable; and enhances the quality of life for farmers and society as a whole.' (American Society of Agronomy, 1989).

From this statement numerous definitions emerged, but the concept surrounding agricultural sustainability remains the same.

Improving agricultural sustainability appears to be one of the most important goals for the near future for most of the countries and has become an international agenda. In that context, several studies have been performed on the environmentally non-degrading, resource conserving, socially acceptable, technically appropriate and economically viable agricultural practices. However, sustainable agriculture has different meanings for different people. Even most precise statement on the meaning of the sustainable agriculture may, and will, produce numerous definitions and practices. For some, it means continuing present farming methods; for others, the focus is on ecological integrity at the expense of any other concerns.

In many developed nations, the concept of sustainable agriculture blends basic economic concerns, conservation, and maintenance or improvement of the resource base. The motivation is derived primarily from environmental and ecological concerns.

In developing countries, farmers' immediate concerns include improving crop yield, increasing crop diversity, and increasing income rather than concern for the environmental issues.

Consequently, it is important to define the concept of sustainable agriculture in the context of the society in which it exists.

\section{FACTORS OF SUSTAINABLE AGRICULTURE}

Traditionally, it is considered that sustainability centres on three pillars: environmental, economic and social. The impact of the activity is considered by, so called, 'Triple Bottom Line (TBL)', i.e. society (people), the environment (planet) and economic value (profit) - Fig. 1(a) (Norman \& MacDonald, 2004; Flint, 2013).

In the three pillars mentioned above, in agriculture system certain factors can be emphasized (Table 1).

The three main goals form a sustainable agricultural system are often affected by other underlying factors. It is more realistic that in some cases, especially in the developing countries, to specifically separate two additional factors; participation and cooperation, and also the level of knowledge - Fig. 1(b). It has been proven that the level of education and participation, both play crucial role as factors of the sustainability of agricultural (D'Souza, Cyphers \& Phipps, 1993; Den Biggelaar and Suvedi, 2000; Bosshaq, Afzalinia \& Moradi, 2012). 


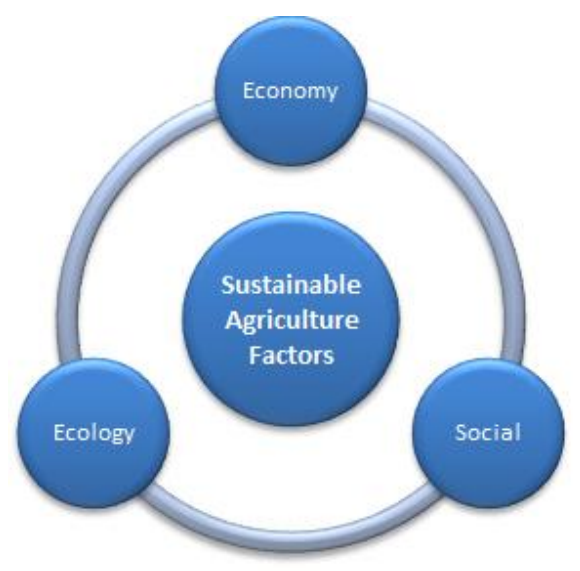

(a) traditional

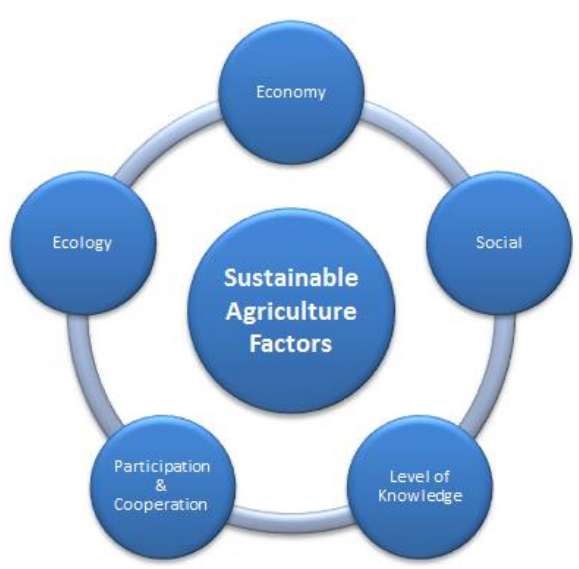

(b) revised

Figure 1: Factors of Sustainable Agriculture

It can be argued that the level of knowledge, which is directly related to level of education, is most likely a decisive factor and superior to the participation. Techniques that are essential for making agriculture sustainable, such as sustainable agronomical operations-orientation (Saifi \& Drake, 2008), including use of advanced irrigation systems, technologies of integrated management of pests combining administration, decrease in the consumption of chemical fertilizers and move toward consuming organic fertilizers and supporting biological variation, can only be achieved with high level of knowledge. Knowledge gives understanding, awareness, responsiveness and consciousness, crucial factors in comprehension and application of proper agricultural solutions. However, participation, which can be considered as part of the social factor in the sustainable agriculture, call for special consideration. It is also directly related to knowledge (participation in training and extension classes), as it may be one of the only way for local farmers to acquire information and know-how. However, participation should be read together with cooperation and collaboration, as taking part in regional and local social activities related to sharing and empowering people, producing new capacities, learning native knowledge, and generally increasing understanding and grasp of practical aspects of sustainable agriculture (Uphoff, 1991; Lorencowicz \& Uziak, 2014). That also calls for support system not only showing the values and benefits of sustainability in agricultural system, but also enhancing production resources of the farming community that leads to improvement of life quality.

Table 1. Elements of Sustainable Agriculture

\begin{tabular}{|c|c|c|}
\hline Environmental dimension & Social dimension & Economic dimension \\
\hline $\begin{array}{ll}\text { - } & \text { environmental } \\
\text { integrity } \\
\text { - } & \text { physical resource base } \\
\text { - } & \text { management of human } \\
\text { - } & \text { ansumption } \\
\text { - } & \text { applied technology }\end{array}$ & $\begin{array}{ll}\text { - } & \text { social acceptability \& } \\
& \text { justice } \\
\text { - } & \text { human settlements } \\
\text { - } & \text { enhanced quality of life } \\
\text { - } & \text { intergenerational equity } \\
\text { - } & \text { human relationship to } \\
& \text { nature }\end{array}$ & 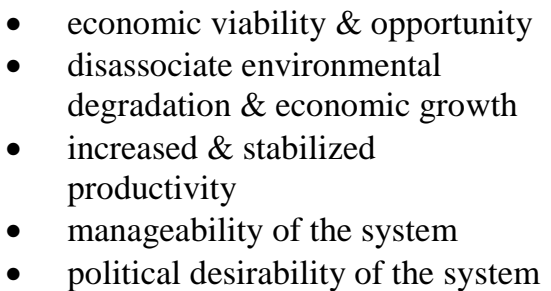 \\
\hline
\end{tabular}

Webster has also emphasized that the improvement of economic conditions of farmer is the most tangible and objective manifestation of advantage of any system which the farmer welcomes (Webster, 1997). The income from the land is, without any doubt, the most, if not the only, concern of some poor smallholder farmer in rural area of almost 
any developing country. Primary, the farmer wants to satisfy his own needs and, possible, sell the surplus produced.

\section{CONSTRAINTS TO IMPLEMENTING SUSTAINABLE AGRICULTURE}

The adoption rates of the sustainable agriculture in developing countries is very low (Andersson \& D'Souza, 2014; Adenle, Azadi \& Manning, 2017; Thierfelde et al., 2017) despite examples of successful adoption of conservation agriculture (Erenstein et al., 2012). The major reason for such situation can be attributed to the fact that simply the need for food in those countries is not met, and that it is certainly the required condition for a transition to more sustainable agriculture. Foremost, practising of the sustainable system has to improve food production to satisfy consumption needs of the farmer's family. The next step is the possibility of selling the surplus to customers.

A vast range of factors are listed by different authors as constraints to sustainable agricultural development in the developing countries. Some authors group them as internal and external (D'Souza, Cyphers \& Phipps, 1993), some as biophysical and socio-economic (Rusinamhodzi, et al, 2014).

Unfortunately, the major constraint for better implementation of practices of sustainable agriculture is political, as the current practices applied in the developing countries do not bring the enough increase in the production. A 'tale' of long-term environmental degradation is not an argument for a farmer who is struggling to feed his family. Therefore, there is a need for economic incentives from the policymakers; whether such approach is 'sustainable' itself is separate question.

There is also a dramatic need for education creating and/or improving awareness and willingness of farmers to participate. Hence, extension services, community training, lacking in developing countries, is a second major constraint.

Another factor, often not recognized, is the political and social instability. Civil wars, or simple fights for natural resources, such common in developing countries, put a problem of sustainable agriculture out of the picture. The same applies to HIV/AIDS, tuberculosis, malaria, cholera and other pandemics ever-present in developing countries. Such tragedies create, if not political, at least social crisis. Once again, the sustainable agriculture looks like a distant issue not worth considering.

\section{CONCLUSIONS}

Most sustainable agriculture attempts in the developing countries are donor-funded and have no mechanism of surviving after the funds for the project dry out. Farming practices are not actually promoting procurement of essential agriculture inputs. The activities of majority of projects are limited to meeting the subsistence needs (Munthali, Mkandawire \& Tembo, 2012).

Majority of smallholder farmers regularly, if not constantly, face numerous challenges and constraints linked to variety of issues, mainly related to limited resources (land, water, funds, labour) and limited access (knowledge, information, inputs, technology, opportunity). In such circumstances, the general importance of economic motivations in facilitating sustainable farm management cannot be overemphasized.

It is unrealistic to expect an awareness and understanding of long term environmental challenges within rural population in the developing countries. However, since any long-lasting and viable solution requires, that sustainable agriculture must be based on 
the needs of local farmers and meeting his expectations, the emphasis should be on providing farmers with tools and techniques to improve their economic conditions. This factor should be the main concern of agricultural policies and agricultural innovation must improve yields, decrease environmental degradation, and be accessible to smallholders.

Learning framework, promoting sustainable agricultural practices should actively educate farmers about the link between these farming practices and biodiversity conservation; such promotion should put special emphasis on benefits for local communities. In general, there is a need to build human capital, so more farmers are more likely to adopt new technologies. Learning activities should be associated with active participation and cooperation, as only factual experience, in successful sustainable agricultural practices improving quality of life, can be indeed effective in accepting and implementing new agricultural approach.

\section{REFERENCES}

Adenle, A.A., Azadi, H. \& Manning, L. (2017). The era of sustainable agricultural development in Africa: Understanding the benefits and constraints. Food Reviews International, DOI: 10.1080/87559129.2017.1300913.

Alexandratos, N. \& Bruinsma, J. (2012). World Agriculture Towards 2030/2050: The 2012 Revision. Food and Agriculture Organization of the United Nations, ESA Working Paper no. 12-03.

Altieri, M.A. \& Toledo, V.M (2011). The agroecological revolution in Latin America: rescuing nature, ensuring food sovereignty and empowering peasants. The Journal of Peasant Studies, 38(3), 587-612.

American Society of Agronomy (1989). Decision reached on sustainable agriculture. Agronomy News. January, 15-16.

Andersson, J.A. \& D’Souza, S. (2014). From adoption claims to understanding farmers and contexts: A literature review of Conservation Agriculture (CA) adoption among smallholder farmers in southern Africa. Agriculture, Ecosystems and Environment, 187, 116-132.

Barro, A, Kondombo, C.P. \& Yelemou, B. (2017). Effects of oxen yoke and donkey collar on traction force and their consequences on sorghum production in the northern Burkina Faso. International Journal of Biological and Chemical Sciences, 11(2), 609-622.

Bosshaq, M.R, Afzalinia, F. \& Moradi, H. (2012). Measuring indicators and determining factors affecting sustainable agricultural development in rural areas - A case study of Ravansar, Iran. International Journal of AgriScience, 2(6), 550-557.

D’Souza, G., Cyphers, D. \& Phipps, T. (1993). Factors affecting the adoption of sustainable agriculture practices. Journal of Agriculture and Resource Economics Review, 22(2), 159-165.

Den Biggelaar, C. \& Suvedi, M. (2000). Farmers' definitions, goals, and bottlenecks of sustainable agriculture in the North-Central Region. Agriculture and Human Values, 17(4), 347-358.

Erenstein, O., Sayre, K, Wall, P., Hellin, J. \& Dixon, J. (2012). Conservation Agriculture in Maize- and Wheat-Based Systems in the (Sub)tropics: Lessons from Adaptation Initiatives in South Asia, Mexico, and Southern Africa. Journal of Sustainable Agriculture, 36, 180-206.

FAO - Food and Agriculture Organization of the United Nations (1995). Sustainable Agriculture and Rural Development. In T. Loftas (Ed.), Dimensions of Need - An Atlas of Food and Agriculture. FAO, Rome, 68-71.

Flint, R.W. (2013). Practice of Sustainable Community Development. Springer Science+Business Media New York, DOI 10.1007/978-1-4614-5100-6_2.

Getnet, F., Feyera, T., Alemu, F., Niguse, A \& Abera, T. (2014). Injuries in Donkeys and Mules: Causes, Welfare Problems and Management Practices in Amhara Region, Northern Ethiopia. American-Eurasian Journal of Scientific Research, 9(4), 98-104. 
Hunter, M.C., Smith, R.G., Schpanski, M.E., Atwood, L.W. \& Mortensen, D.A. (2017). Agriculture in 2050: Recalibrating Targets for Sustainable Intensification. BioScience, 67(4), 386-391.

Lorencowicz E. \& Uziak J. (2014). Farmers collaboration - the way for improving sustainability. In E. Lorencowicz, F. Baptisa, L.L. Silva \& Marques da Silva J.R. (Eds.), Sustainable agriculture PolandPortugal. Lublin-Evora, (ISBN 978-83-937433-1-5), 99-110.

Loukanov, I.A., Uziak, J. \& Michálek, J. (2005). Draft Requirements of Enamel Coated Animal Drawn Mouldboard Plough. Research in Agricultural Engineering, 51(2), 56-62.

Munthali, S.M., Mkandawire, R.M. and Tembo, N. (2012). Sustainable Agriculture - A Panacea for Achieving Biodiversity Conservation and Rural Development in Sub-Saharan Africa? In R.S. Adisa (Ed.), Rural Development - Contemporary Issues and Practices. ISBN: 978-953-51-0461-2, InTech.

Norman, W. \& MacDonald, C. (2004). Getting to the Bottom of "Triple Bottom Line". Business Ethics Quarterly, 14(2), 243-262.

Rusinamhodzi, L., Ngwira, A.R., Mupangwa, W., Nyagumbo, I., Kassie, G.T \& Cairns, J.E. (2014). Conservation agriculture in Southern Africa: advances in knowledge. Renewable Agriculture and Food Systems, doi:10.1017/S1742170513000550.

Saifi. B. \& Drake, L. (2008). A co evolutionary model for promoting agricultural sustainability. Ecological Economics, 65, 24-34.

Thierfelder, C., Rusinamhodzi, L., Ngwira, A.R., Mupangwa, W., Nyagumbo, I., Kassie, G.T \& Cairns, J.E. (2014). Conservation agriculture in Southern Africa: Advances in knowledge. Renewable Agriculture and Food Systems, Cambridge University Press, 1-21 doi:10.1017/S1742170513000550.

Tilman, D., Blazer, C., Hill. J. \& Befort, B.L. (2011). Global food demand and the sustainable intensification of agriculture. Proceedings of the National Academy of Sciences, 108: 20260-20264.

Toenniessen, G., A. Adesina, \& DeVries, J. (2008). Building an alliance for a Green Revolution in Africa. In S. Kaler \& O. Rennert (Eds), Reducing the Impact of Poverty on Health and Human Development: Scientific Approaches, Oxford: Blackwell Publishing.

Uphoff, N. (1991). Fitting Projects to People. In M.M. Cernea (Ed.), Putting People First: Sociological Variables in Rural Development (pp. 467-511). New York and Oxford University Press.

Uziak, J. \& Loukanov, I.A. (2007). Ram Press Oil Extraction: Sustainable Technology for Small Scale Farming in Sub-Saharan Africa. International Journal of Agriculture and Rural Development, 10(1), 161165.

Webster, J.P.G. (1997). Assessing the economic consequences of sustainability in agriculture. Agriculture, Ecosystems \& Environment 64, 95-102. 